\title{
INFORMATION CONCERNING CONFERENCES OF INTEREST TO READERS
}

\author{
Fourth International Biophysics Congress
}

7-14 August 1972, Moscow, U.S.S.R.

1. Symposium on Biorheology

The Congress will be under the sponsorship of the International Union of Pure and Applied Biophysics (IUPAB) and the Academy of Sciences of the USSR. The Congress will include symposia of invited papers on topics of particular interest at the moment, and sessions for contributed papers. Our Society, as an Affiliated Commission of the IUPAB, was invited to organize a symposium on Biorheology. The organizing committee for this symposium comprises A. L. Copley (Chairman), G. V. F. SEAman, A. Silberberg and V. I. VoroB'EV.

Languages. English, French, German and Russian will be the official languages of the Congress. Simultaneous translation will be available in English and Russian for the symposia only. The deadline for the submission of Free Communications has already passed.

For further information regarding the Congress write to:

Professor L. P. KAYUSHIN

Secretary-General, Organizing Committee

IV International Biophysics Congress

Profsoyuznaya 7

Moscow, V-133, U.S.S.R.

The Seventh Conference of the European Society for Microcirculation

(International Microcirculation Conference)

26 August-1 September 1972, Aberdeen, Scotland

Information and the necessary forms may be obtained from Professor A. L. STALKeR, Department of Pathology, University of Aberdeen, Aberdeen AB9 2ZD, Scotland. The planned symposia are:

"The ultrastructural and electrochemical basis of red cell aggregation" (Prof. SHU CHIEN).

"The light microscope in microvascular research" (Dr. J. IRWIN).

"The obstetric aspects of DIC" (Prof. C. L. SCHNEIDER).

"The interaction of blood and endothelium" (Dr. A. S. ToDD).

There will also be demonstrations, films, and a stop-press session. The conference registration fee will be $£ 20$ for full participants.

III Congress the International Society on Thrombosis and Haemostasis

$$
\text { 22-26 August 1972, Washington D.C., U.S.A. }
$$

The Third International Congress on Thrombosis and Haemostasis, jointly sponsored by the International Society on Thrombosis and Haemostasis and the Council on Thrombosis of the American Heart Association will be held at the Mayflower Hotel, Washington D.C. The revised deadline for receipt of abstracts is 1 April 1972. For further information, registration and hotel reservations contact HAROLD R. ROBERTS, M.D. Chairman Organizing Committee P.O. Box 630, Chapel Hill, N.C. 27514, U.S.A. 


\title{
XIV International Congress of Hematology
}

\author{
16-21 July 1972, São Paulo, Brazil
}

For further information write to:

\author{
Secretaria General \\ XIV Congresso Internacional de Hematologia \\ Rua Gabriel dos Santos, 443 \\ São Paulo, 4, SP Brasil
}

Eighth Meeting: Federation of European Biochemical Societies

20-25 Algust 1972, Amsterdam, Netherlands

This meeting has been organized for the Federation by the "Nederlandse vereniging voor Biochemie" and includes a symposium on Biomembranes: molecular arrangements and transport mechanisms, organized by L. L. M. van DeEnen, J. C. RIemersma and J. M. TAGer. For further information, contact Secretariat, P.O. Box 7205, Amsterdam, The Netherlands.

\section{Conference Reports on Recent Meetings of Biorheological Interest}

A. Symposium on Polymeric Materials in Artificial Organs

17-19 November 1971, California Institute of Technology, Pasadena, California, U.S.A.

The symposium was sponsored by the polymer group of the Southern California Section of the American Chemical Society and was chaired by Dr. N. W. TSCHOEGL.

\section{Introduction}

S. SobIN, School of Medicine, USC:

Compatibility problems in artificial organs

Cardio-pulmonary devices

F. LAU, School of Medicine, USC:

Cardio-pulmonary physiology and normal valve function

J. KAY, School of Medicine, USC:

Valvular heart surgery

E. J. RoschKe, JPL, Caltech:

An engineer's view of prosthetic heart valve performance

R. JUNG, School of Medicine, USC:

Membrane oxygenators: problems of long term use

S. BRUCK, NIH:

Polymeric materials: current status of biocompatibility

J. Moacanin, JPL, Caltech:

Polymeric materials: prediction of mechanical performance

Hard and soft tissues

A. S. Hoffman, Chemical Engineering and Bioengineering, University of Washington and Batelle, Seattle Research Center:

A materials engineering view of hard and soft tissues

C. W. Hall, Southwest Research Institute, San Antonio, Texas:

Soft tissues interfacing with fabrics

M. T. KARAGIANES and K. R. WhEELER, Battelle Seattle Research Center:

Porous metals as a hard tissue substitute

D. E. GRenoble and D. MARKLE, School of Dentistry, USC:

The physical and chemical properties of hard tissues 
General papers

P. N. SAWyer, D. J. Bentley and J. C. Bivona, Jr.:

Development and evaluation of a new pulsatile ventricle pump for use in cardiopulmonary by-pass

F. E. Marton and C. W. Saltonstall, JR.:

Improved hemodialysis membranes

C. L. Hu:

Blood clotting on polyethylene walls as affected by applied electric field

F. J. SCHOEN and D. P. SNOWDEN:

Flexible carbon coated polymers for biomedical application

E. E. SPaETh, N. M. DAS, L. C. Grudice and R. M. Hochmuth:

Adhesion of blood cells to artificial surfaces in the presence of flow

B. M. CHU:

Differences and similarities in the mechanical response of soft living animal tissue and filled polymeric materials

N. E. BURns:

Mass production of silicone rubber membranes for medical use

A. Rembaum, S. P. S. Yen, M. Ingram, J. F. Newton, JR., C. L. Hu and W. G. Frasher

Platelet deposition on heparin-bonded and heparin-free surfaces

Artificial kidney

F. L. ORELL, School of Medicine, USC:

Dialysate delivery systems, dialysers and related devices

D. J. LYMAN, U. of Utah:

Membranes in artificial kidney devices--past, present and future

B. H. BARBOUR, School of Medicine, USC:

Medical problems associated with patients on chronic hemodialysis

M. B. WoLF, Biomedical Engineering, USC:

Computer models

B. American Institute of Chemical Engineers Symposium on Rheology of Biological Systems

November 1971, San Francisco, California, U.S.A.

The interest of chemical engineers in biorheology has grown tremendously in recent years. This symposium concentrated on two areas or research; Part I, which emphasizes the effects of red cell deformation on blood rheology and Part II, which was mainly concerned with biological lubricants. Panel discussions followed the formal presentation at each session. The conference was held under the co-chairmanship of H. L. GABELNICK, Bethesda, Md., USA and Mr. Litr, University of Pennsylvania, Philadelphia, Pa., U.S.A.

\section{Introduction}

H. L. GABELNiCK and N. I. H. Bethesda, Maryland, U.S.A.

R. Wells, Peter Bent Brigham Hospital, Massachusetts, U.S.A. and J. Goldstone, University of California Medical Center, San Francisco, California, U.S.A.

Rheology of the human red cell and capillary blood flow

R. N. MacCallum, W. O'Bannon, and J. D. Hellums, Rice University, Houston, Texas, U.S.A., and E. C. LYNCH, Baylor College of Medicine, Houston, Texas, U.S.A.

Viscometric studies on red blood cell damage.

A. R. Perlin and T. K. Hung, Carnegie-Mellon University, Pittsburgh, Pennsylvania, U.S.A. and G. BugLIARELlo, University of Illinois at Chicago Circle, Chicago, Illinois, U.S.A.

A numerical analysis of the flow of deformable erythrocyte models in capillaries.

J. S. Ultman, The Pennsylvania State University, University Park, Pennsylvania, Pa.

The recoverable membrane energy as the criterion of red cell hemolysis

M. LITT and R. LUTZ, University of Pennsylvania, Philadelphia, Pennsylvania, U.S.A.

Physical chemical factors in mucus rheology

S. S. DAvIS, University of Aston, Birmingham, U.K.

Rheological examination of sputum and saliva and the effects of drugs

C. D. HAN, Polytechnic Institute of Brooklyn, Brooklyn, New York, USA and B. Barnes and E. Meilman, Long Island Jewish Hospital, Long Island, New York, U.S.A. 
Measurement of the rheological properties of biological fluids

A. M. BeNIS, Department of Chemical Engineering, Columbia University New York, U.S.A. and E. PUCHELLE and P. SAdoul., Faculté de Médecine de Nancy, Physiopathologie Respiratoire, Nancy, France.

Study of the viscoelastic properties of Sputum with a concentric cylinder rheology

P. S. WALKeR, Hospital for Special Surgery, New York, N.Y. U.S.A. and R. Roth, Hydron Laboratories, New Brunswick, New Jersey, U.S.A.

The rheology of hydron for orthopaedic implants

C. A. Homsy, R. F. StanLEY and J. W. KING, Baylor College of Medicine, Houston, Texas, U.S.A.

Pseudo-synovial fluids based on NaCMC-in vitro and in vivo applications

\section{Twentieth Annual Meeting of the Microcirculatory Society}

$$
\text { 8-9 April 1972, Colony Motel, Atlantic City, USA }
$$

The following papers of biorheological interest will be presented:

T. P. Bond and M. M. Guest:

Microvascular flow after exposure to snake venoms

W. I. Rosenblum:

A possible role for mast cells in the regulation of cerebral circulation

J. H. BARBEE and G. R. CoKelET:

The flow of human blood through small capillary tubes

S. K. YU and H. L. GoldsMiTH:

Flow behaviour of blood cells at obstructions in tubes

S. USAMI and S. CHIEN:

Quantitation of red cell aggregation under shear flow

R. JENDRUCKO and J. S. LEE:

Transmission photometry of blood flowing in glass capillaries

R. Wells and G. Halikas:

Morphological differences in thrombi formed at low and high flow rates

M. P. Wiedeman and E. H. MARGULies:

Platelet aggregates in microvessels

J. R. Fox and C. A. WIEDERHIELM:

Relationship between electrical resistance and pressure in glass micropipets

J. F. Gross and M. INTAGLIETTA:

Mass transfer in the pulsatile microcirculation

A. C. Groom and S. H. Song:

Slow clearance of reticulocytes from a vascular bed

Y. C. FUNG:

The stochastic characteristics of capillary blood flow

A. FRONEK and T. WITZEL:

Evaluation of new criteria for capillary pressure determination

J. J. Friedman:

Sympathetic influence on pre- and post-capillary resistance

K. FRONEK and B. ZWEIFACH:

Pre- and post-capillary resistances and their intrinsic control

Thrombosis Research

An International Journal on Vascular Obstruction, Hemorrhage and Hemostasis.

Editors-in-Chief: Alfred L. Copley, New York, U.S.A. and BIRGER BloMBäcK, Stockholm, Sweden.

The first issue of this new bi-monthly journal to be published by Pergamon Press is scheduled for February 1972, to be followed by the second issue in April 1972.

It is intended that the journal should serve as a world forum for the rapid dissemination of original research on thrombus formation, thrombo-embolization, hemorrhage due to alterations of the blood vessel wall and/or defects in hemostasis, and other related hemorheological disturbances which impair circulation. The Editors welcome scientific contributions which give new directions to research on thrombosis and allied pathological conditions. The Journal's policy encourages the publication of manuscripts of research concerning these conditions, including clinical investigations which will lead to new approaches in diagnosis, therapy, prognosis and prevention of thrombosis and other hemorheological diseases or disorders. 
Books of Biorheological Interest

Elementary Rheology G. W. Scott Blair, Grist Cottage, Iffley, Oxford, England. Academic Press, London, 1969, 158 pages.

Rheology of the Circulation R. L. Whitmore, The University of Queensland, Brisbane, Australia, Pergamon Press, Oxford, 1968, 196 pages.

Dextrans-Current Concepts of Basic Actions and Clinical Applications (Edited by John R. Derrick and M. Mason Guest), University of Texas Medical Branch, Galveston, Texas, U.S.A. Charles C. Thomas, Springfield, Illinois, U.S.A, 1971, 222 pages.

Microcirculation et Hémorheologie A. LARCAN and J. F. Stoltz, Centre Hospitalier Régional de Nancy, Nancy, France. Masson \& Cie, Paris, 1970, 274 pages.

Blood Microrheology Viscosity Factors in Blood Flow, Ischaemia and Thrombosis Leopold DinTenfass, University of Sydney, Sydney, Australia. Butterworths, London, U.K., 1971, 444 pages. 